\title{
A RESTING CELL SYSTEM FOR EFROTOMYCIN BIOSYNTHESIS
}

\author{
J. B. K. NIELSEN and L. KAPLAN \\ Merck \& Co., Inc., \\ P.O. Box 2000, NJ 07065-0900, U.S.A.
}

(Received for publication December 12, 1988)

\begin{abstract}
Efrotomycin, a modified polyketide antibiotic with utility as a growth permittant in the animal industry, is produced by Nocardia lactamdurans. A resting cell system has been developed to facilitate biosynthetic studies. Washed cells harvested from oil-based medium at 64 hours and resuspended in buffer produce up to $700 \mathrm{mg} / \mathrm{ml}$ efrotomycin in 60 hours when supplemented with a carbon source, optimally glucose. No evidence of carbon or nitrogen repression was observed. Productivity declines progressively with cell age but becomes less dependent on ongoing protein synthesis. The protein synthesis dependent and independent systems were used to study carbon utilization, incorporation of labeled precursors and to examine inhibitors of efrotomycin biosynthesis. A system derived from an efrotomycin non-producer was used to examine the glycosylation of the aglycone, aurodox, to efrotomycin through a monosaccharide form, $6^{\prime}$-deoxyallosyl aurodox.
\end{abstract}

Efrotomycin is an antibiotic of the elfamycin family with utility as a growth permittant in swine and chickens ${ }^{1)}$. It is the disaccharide of aurodox or X-5108, as it was first called ${ }^{2)}$, and exhibits the pattern of labeling by acetate, propionate, butyrate and methyl groups of methionine established for aurodox ${ }^{3)}$. The structure of the disaccharide moiety has recently been established as 6-deoxy-4-O(6-deoxy-2,4-di- $O$-methyl- $\alpha$-L-mannopyranosyl)-3-O-methyl- $\beta$-D-allopyranose attached via an $\alpha$ linkage from the allose $\mathrm{C}_{1}$ to the hexahydropyran substructure of aurodox (Fig. 1) ${ }^{4}$. The three $O$-methyl groups on the sugar residues are derived from the methyl group of methionine and the rest of the carbon probably arises from glucose units.

The origin of the pyridone ring and of the peptide bond are unknown. No intermediates have been isolated and the sequence of macrolide condensations, glycosylations, and methylation is unknown. To facilitate biosynthetic studies a resting cell system has been developed. It has provided a simple

Fig. 1. The structure of efrotomycin.<smiles>C/C=C\C=C\C1OC(O)(C(C)C(=O)NC/C=C/C=C(\C)C(OC)C(C)C2OC(/C=C/C=C/C=C(\C)C(=O)c3c(O)ccn(C)c3=O)C(O)C2O)C(O)C(OC2OC(C)C(OC3OC(C)C(OC)C(O)C3OC)C(O)C2OC)C1(C)C</smiles> 
means of examining the incorporation of isotopically labeled precursors, the effect of compounds on biosynthesis and the conversion of aurodox to efrotomycin.

A preliminary account of this work has been reported elsewhere ${ }^{5}$.

\section{Materials and Methods}

\section{Cultures}

Nocardia lactamdurans, MA5887, was maintained on slants or as frozen vegetative mycelia in NYG seed medium containing in $\mathrm{g} /$ liter; nutrient broth 4 , yeast extract 2, and glucose 10. After a 20-hour seed stage in NYG medium at $26^{\circ} \mathrm{C}$, cells were grown in YEME containing in $\mathrm{g} /$ liter; yeast extract 10 , malt extract 10 , and glucose 10 , or a soy bean oil-based production medium for 64 hours at $26^{\circ} \mathrm{C}$ or longer as noted. The cells were harvested by centrifugation at $3,000 \mathrm{rpm}$ for 15 minutes, washed twice with distilled water, and resuspended at approximately $30 \mathrm{mg}$ dry weight $/ \mathrm{ml} \mathrm{in} 0.1 \mathrm{M}$ Tris- $\mathrm{HCl}$, $\mathrm{pH}$ 8.0. This suspension, at 2 times final concentration, can be stored for up to 24 hours at $4^{\circ} \mathrm{C}$ without loss of synthetic capacity.

\section{Resting Cell Incubation}

Incubations were performed in volumes ranging from $0.5 \mathrm{ml}(16 \times 125 \mathrm{~mm}$ tubes) to $2.5 \mathrm{ml}$ ( $25 \times$ $180 \mathrm{~mm}$ tubes) or up to $40 \mathrm{ml}$ in a $250-\mathrm{ml}$ Erlenmeyer flask at $26^{\circ} \mathrm{C}$ at $220 \mathrm{rpm}$ in a gyratory shaker with the addition of a carbon source, $1.2 \%$ glucose, as noted, and with $0.1 \mu \mathrm{g} / \mathrm{ml}$ vitamin $\mathbf{B}_{12}$. There is no increase in dry cell weight for cells harvested at age $40 \sim 120$ hours during the resting cell incubation period.

Inhibition of protein synthesis by chloramphenicol was assessed by the rate of incorporation of ${ }^{35}$ S]methionine (New England Nuclear) at a concentration of $1 \mu \mathrm{g} / \mathrm{ml}$ and a specific activity of 124 $\mu \mathrm{g} / \mu \mathrm{mol}$. After incubation at $30^{\circ} \mathrm{C}$, with shaking, for various lengths of time, $0.1 \mathrm{ml}$ of cells was placed on Whatman $3 \mathrm{~mm}$ filter paper. The filters were washed successively in cold $10 \% \mathrm{TCA}$, hot $10 \%$ TCA, twice in cold $3 \%$ perchloric acid, twice in ethanol, dried, and counted in a scintillation counter.

Glutamine synthetase was assayed as described for Streptomyces cattleya $\left.{ }^{6}\right)$ and lipase by radioactive tripalmitate hydrolysis ${ }^{\text {? }}$.

\section{Analytical Procedures}

Efrotomycin was assayed by a colorimetric procedure using $\mathrm{AlCl}_{3}{ }^{8}$. The aglycone, aurodox, and its monosaccharide react equally in the $\mathrm{AlCl}_{3}$ color reaction. The three forms can be separated and assayed by HPLC using a Hamilton PRP-1 column, and isocratic elution with $0.03 \mathrm{M}$ ammonium phosphate $\mathrm{pH} 7.0$ and acetonitrile $(67: 33)$ at ambient temperature and a flow rate of $1.2 \mathrm{ml} / \mathrm{minute}$. The relative retention times for the monosaccharide, aurodox and the disaccharide, efrotomycin are $0.43,0.57$ and 1.0. The forms may also be separated by TLC on silica plates containing $F_{254}$ indicator developed in chloroform - methanol $(4: 1)$. The Rf values of monosaccharide, aurodox and efrotomycin are $0.49,0.62$ and 0.69 , respectively. Duplicate determinations on a single sample agree within $3 \%$. All the determinations cited are the results of analyzing duplicate samples and agreed within $5 \%$.

A non-producing mutant (np15) was obtained following UV treatment at $1 \%$ survival of fragmented cells. The suspension for mutagenesis was prepared by gentle removal with glass beads of aerial mycelium grown for 7 days at $28^{\circ} \mathrm{C}$ on confluently plated $1 / 3 \mathrm{ELG}$ agar containing in $\mathrm{g} /$ liter; yeast extract 0.33, NZ-Amine Type E (Sheffield Chemical) 0.66, meat extract (Difco) 0.33, glycerol 10, sucrose $20, \mathrm{CaCl}_{2} \cdot 2 \mathrm{H}_{2} \mathrm{O} 1.47, \mathrm{MgCl}_{2} \cdot 6 \mathrm{H}_{2} \mathrm{O} 2.03$, agar 20. Survivors were plated on $1 / 3 \mathrm{ELG}$ agar and then patched onto isolated wells of the same medium composition. A 7-mm plug of each was removed at 7 days for bioassay with the indicator organism Bacillus cereus (Difco). Zones of inhibition of $21 \pm 1 \mathrm{~mm}$ are seen with MA5887. np15 was selected as it did not produce any inhibitory component. It does not synthesize any efrotomycin-like products when assayed by either HPLC or TLC subsequent to growth in liquid medium.

Aurodox was obtained from Dr. PhILlip Miller, then at Hoffmann-LaRoche, Inc., Nutley, 
NJ 07110, U.S.A. Thiolactomycin was obtained from Chugai Pharmaceutical Co., Ltd., Takada, Toshima-ku, Tokyo 171, Japan.

\section{Results}

\section{Derivation of Resting Cell System}

Early studies on washed cells derived from medium YEME gave rise to a system producing 50 $\mu \mathrm{g} / \mathrm{ml}$ efrotomycin after 48 hours incubation. This could be increased to $200 \mu \mathrm{g} / \mathrm{ml}$ by the addition of an exogenous carbon supply, optimally $1.2 \%$ glucose, but was not further increased by any additional supplementation of amino acids. A more productive system was derived from cells harvested from a soy bean oil-based complex production medium. Productivity, stimulation by exogenous carbon source and dependence upon continuing protein synthesis vary significantly with cell age. The kinetics of efrotomycin synthesis (over 64 hours incubation period), are shown in Fig. 2, without added carbon source and with glucose or soy bean oil. The only other stimulatory additive is vitamin $\mathbf{B}_{12}$. At $0.1 \mu \mathrm{g} / \mathrm{ml}$, it stimulates glucose-supplemented production by $15 \sim 20 \%$ (Fig. 2), and non or oil supplemented production by $5 \sim 10 \%$.

The ability of other carbon sources to support production is shown in Table 1, for incubation carried out for 64 hours. Dextrin and all the disaccharides tested are inactive, and no sugar is more active than glucose. In contrast to cells grown in YEME medium, cells pregrown in the oil-based complex medium are capable of using oil as a carbon source, although with a lag relative to glucose (Fig. 2). The ability to use oil depends upon the induction of lipase during the growth phase prior to harvesting of the cells. If soy bean oil is replaced in the growth medium by glycerol, lipase is not induced and oil cannot be

Fig. 2. Production of efrotomycin $(\mu \mathrm{g} / \mathrm{ml})$ by oilderived cells obtained after 64 hours of growth harvested at 64 hours.

- No added carbon source, $\triangle$ soy bean oil 40 $\mathrm{mg} / \mathrm{ml}, \square$ glucose $12 \mathrm{mg} / \mathrm{ml}$, glucose $12 \mathrm{mg} / \mathrm{ml}+$ vitamin $B_{12} 0.1 \mu \mathrm{g} / \mathrm{ml}$.

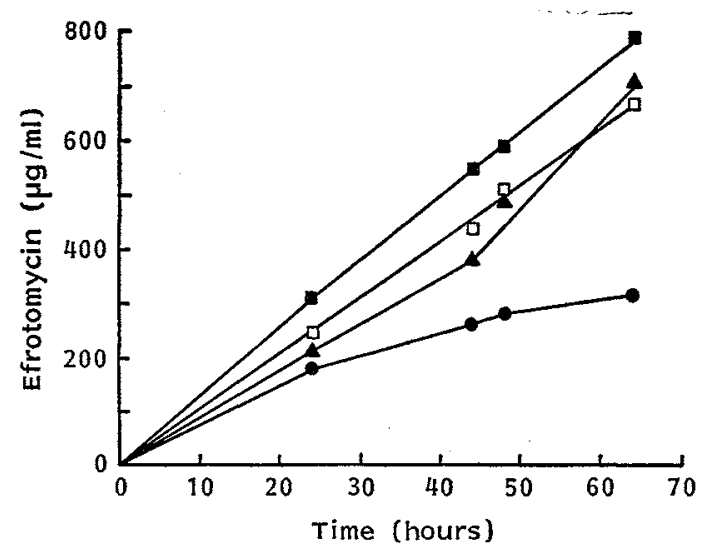

Table 1. The effect of various carbon sources on efrotomycin synthesis by MA5887.

\begin{tabular}{|c|c|c|}
\hline & $\begin{array}{l}\text { Addition } \\
(\%)\end{array}$ & $\begin{array}{l}\text { Production of } \\
\text { efrotomycin } \\
\text { at } 64 \text { hours } \\
\% \text { relative to } \\
\text { glucose }^{2}\end{array}$ \\
\hline \multicolumn{2}{|l|}{ No addition } & 46 \\
\hline \multicolumn{2}{|l|}{ Glucose } & 100 \\
\hline Mannose & 1.2 & 72 \\
\hline Mannitol & 1 & 89 \\
\hline Sorbose & 1 & 50 \\
\hline Sorbitol & 1 & 74 \\
\hline Galactose & 1 & 85 \\
\hline$\alpha$-Methyl glycoside & 1 & 47 \\
\hline Fructose & 1.2 & 76 \\
\hline Arabinose & 1.2 & 83 \\
\hline Ribose & 1.2 & 83 \\
\hline Melibiose & 1 & 77 \\
\hline Lactose & 1 & 48 \\
\hline Sucrose & 1 & 47 \\
\hline Maltose & 1 & 25 \\
\hline Dextrin & 1 & 50 \\
\hline Glycerol & 2 & 72 \\
\hline Oil & 2 & 106 \\
\hline \multicolumn{3}{|c|}{$\begin{array}{l}\text { Glucose supplemented productivity was } 660 \\
\mu \mathrm{g} / \mathrm{m} 1 \text {. The results are an average of two ex- } \\
\text { periments. } \\
\text { Each was added at its optimal level to cells } \\
\text { harvested at } 64 \text { hours and incubated for } 64 \text { hours } \\
\text { after carbon source addition. }\end{array}$} \\
\hline
\end{tabular}


Table 2. Production of aurodox, monosaccharide (MS) and efrotomycin by resting cells.

\begin{tabular}{|c|c|c|c|c|c|c|}
\hline \multirow{2}{*}{$\begin{array}{l}\text { Age of } \\
\text { cells } \\
\text { (hours) }\end{array}$} & \multirow{2}{*}{$\begin{array}{l}\text { Initial } \\
\text { glucose } \\
(\%)\end{array}$} & \multicolumn{4}{|c|}{ Productivity $(\mu \mathrm{g} / \mathrm{ml})$} & \multirow{2}{*}{$\begin{array}{l}\text { Stimulation } \\
\text { by glucose }\end{array}$} \\
\hline & & Efrotomycin & MS & Aurodox & Total & \\
\hline \multirow[t]{2}{*}{29} & - & 26 & 12 & 64 & 102 & \\
\hline & 1.2 & 34 & 31 & 35 & 100 & 1.0 \\
\hline \multirow[t]{2}{*}{40} & - & 68 & 14 & 28 & 110 & \\
\hline & 1.2 & 97 & 39 & 20 & 156 & 1.5 \\
\hline \multirow[t]{2}{*}{48} & - & 126 & 9 & 7 & 142 & \\
\hline & 1.2 & 148 & 105 & - & 253 & 1.8 \\
\hline \multirow[t]{2}{*}{64} & 一 & 125 & 6 & 6 & 137 & \\
\hline & 1.2 & 230 & 30 & - & 260 & 1.9 \\
\hline \multirow[t]{2}{*}{96} & - & 171 & 15 & 10 & 196 & \\
\hline & 1.2 & 200 & 35 & - & 235 & 1.2 \\
\hline \multirow[t]{2}{*}{120} & - & 173 & 17 & - & 190 & \\
\hline & 1.2 & 175 & 33 & - & 208 & 1.1 \\
\hline
\end{tabular}

Cells were harvested at various ages and incubated with and without glucose for 16 hours under resting cell conditions.

utilized by washed cells.

\section{Glycosylation Reactions}

Total productivity and the degree of glycosylation found upon analysing efrotomycinrelated products vary with harvest age (Table 2). Cells harvested at 40 hours and younger show little glucose stimulation and a relatively high proportion of the underglycosylated forms, aurodox and its monosaccharide. The monosaccharide appears in HPLC analysis of incubations as an early eluting peak with an retention time $\left(R_{T}\right)$ of 3.2 minutes. It was identified (B. ARISON and J. SMITH; personal communication) by NMR and mass spectrophotometric analysis as $6^{\prime}-$
Fig. 3. Conversion of aurodox (O), to 6 '-deoxyallosyl aurodox ( $\mathbf{\Lambda})$ and efrotomycin $(\bullet)$ in resting cells of np15.

Each form is expressed as a percentage of the total HPLC-analyzed material.

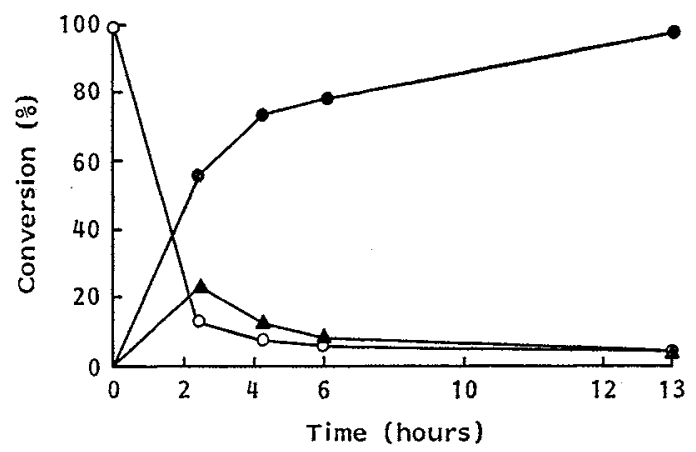
deoxyallosyl aurodox, a monosaccharide lacking the $3^{\prime}$-methyl group present in efrotomycin. Very little aurodox is seen in cells harvested at 48 hours or older even in the absence of glucose, but appreciable amounts of the monosaccharide are seen longer than 16 hours of resting cell incubation at all harvest ages. With longer resting cell incubation periods, for cells harvested at 64 hours or later, essentially all the product is fully glycosylated.

A resting cell system derived from a non-producing mutant of MA5887, np15, converts aurodox to efrotomycin through an intermediate form identical with that found in resting cell incubations as described above. The kinetics of this conversion is shown in Fig. 3 for 72 hours resting cells prepared from np15. Cells harvested at 96 or 120 hours show similar but faster conversion. 6'-Deoxyallosyl aurodox added to this non-producing mutant cells under resting conditions is fully converted to efrotomycin, presumptive evidence that this is an intermediate.

\section{Dependence of Resting Cell System on Protein Synthesis}

Chloramphenicol $(50 \mu \mathrm{g} / \mathrm{ml})$ inhibits the incorporation of $\left[{ }^{35}\right.$ S]methionine into protein by $98 \%$ 
Table 3. Effect of chloramphenicol on resting cell synthesis of efrotomycin as a function of the age of cells employed.

\begin{tabular}{cc}
$\begin{array}{c}\text { Age of cells } \\
\text { (hours) }\end{array}$ & $\begin{array}{c}\text { Inhibition by } \\
\text { chloramphenicol } \\
(\%)\end{array}$ \\
\hline 29 & 85 \\
40 & 72 \\
48 & 65 \\
64 & 47 \\
96 & 35 \\
120 & 21
\end{tabular}

Production is the sum of efrotomycin and underglycosylated forms after 16 hours resting cell incubation, without exogenous carbon source. Chloramphenicol, when used, is at $50 \mu \mathrm{g} / \mathrm{m} 1$.

in N. lactamdurans within 2 minutes of addition, and is more than $95 \%$ inhibitory for the subsequent 18 hours. After 24 hours about $20 \sim 40 \%$ recovery of $\left.{ }^{35} \mathrm{~S}\right]$ methionine incorporation is seen, possibly due to inactivation of chloramphenicol to a subinhibitory level since full inhibition can be maintained by a second addition of $25 \mu \mathrm{g} / \mathrm{ml}$ chloramphenicol at 18 hours. The uninhibited protein synthetic rate varied little over the age range shown in Table 3 , diminishing only slightly with 120 hours cells compared with younger cells. Table 3 shows the effect of inhibiting protein synthesis on efrotomycin productivity in resting cells without exogenous carbon source. The effect in the presence of glucose or oil was similar. Thus at all ages maximal synthesis of efrotomycin is dependent upon ongoing protein synthesis. However, in cells harvested at 64 hours or later, this dependence is reduced to less than $50 \%$. Such cells, treated with chloramphenicol, are suited to a study of inhibitors or activators of efrotomycin synthesis which are relatively independent of effects on protein synthesis.

As shown above, there is no evidence for glucose inhibition of efrotomycin synthesis under resting cell conditions. Similarly, no evidence was found for nitrogen repression. $\mathrm{NH}_{4} \mathrm{Cl}$ up to $50 \mathrm{~mm}$ is completely without effect under these conditions, although amounts as low as $5 \mathrm{mM} \mathrm{NH}_{4} \mathrm{Cl}$ cause rapid, reversible and nearly complete inactivation of glutamine synthetase, demonstrating its ready access to the cell. Phosphate is inhibitory with an $\mathrm{IC}_{50}$ of $2 \mathrm{mM}$ (Table 4). Thus of these common repressors of secondary metabolism only phosphate has a clear inhibitory effect in the relative absence of protein synthesis.

\section{Stimulation and Inhibition of Efrotomycin Synthesis}

Resting cells harvested at 96 hours, treated with $50 \mu \mathrm{g} / \mathrm{ml}$ chloramphenicol and incubated with no exogenous carbon source were used to search for effectors of efrotomycin synthesis. No amino acid, either singly or in combinations stimulates production beyond that shown by glucose or oil 
addition. Among vitamins, cofactors and trace elements examined, only vitamin $B_{12}$ at $0.1 \mu \mathrm{g} / \mathrm{ml}$ is stimulatory, increasing efrotomycin synthesis by $15 \sim 20 \%$ over the whole time course (Fig. 2). Vitamin $B_{12}$ is now routinely added to resting cell incubation. The addition to the resting cell incubation of trace elements used in the growth media $\left(\mathrm{Fe}^{2+}, \mathrm{Mg}^{2+}, \mathrm{Ca}^{2+}, \mathrm{Mn}^{2+}, \mathrm{Mo}^{2+}, \mathrm{Cu}^{2+}\right.$ and $\left.\mathrm{BO}_{4}{ }^{2-}\right)$ have no effect. Failure to add $\mathrm{Fe}^{2+}$ at $50 \mathrm{mg}$ /liter to the pregrowth media results in 5 -fold lower efrotomycin productivity even though growth is barely affected.

$\mathrm{The} \mathrm{IC}_{30}$ for a variety of inhibitors are listed in Table 4. Oxidative phosphorylation inhibitors, arsenite and arsenate were inhibitory. Cobalt, cadmium and zinc are the only inhibitory metals found. The metal chelators EDTA and $o$-phenanthroline cause lysis of the cells at only slightly higher levels than their $\mathrm{IC}_{50}$ (about 2-fold), suggesting that the inhibitory effects seen are due to non-specific membrane disruption. All membrane perturbants tested are inhibitory at fairly low concentrations.

The fatty acid synthesis inhibitor, cerulenin, inhibits efrotomycin synthesis with an $\mathrm{IC}_{50}$ of 0.14 $\mathrm{mM}(30 \mu \mathrm{g} / \mathrm{ml})$, a sensitivity similar to that reported for the synthesis of several macrolides by OMURA ${ }^{9}$. Degradation of cerulenin to subinhibitory levels occurs under resting cell conditions as noted in some other systems. Thiolactomycin is reported ${ }^{102}$ to be a selective inhibitor of type II fatty acid synthetases, the monomeric acyl carrier protein dependent synthase present in many bacteria. Type I synthases, the multimeric form found in mammals and yeast, are unaffected. Thiolactomycin has no effect on efrotomycin synthesis in resting cells. It is apparently taken up by the cell, since growth of $N$. lactamdurans is inhibited by $5 \mu \mathrm{g} / \mathrm{ml}$.

The inhibition of efrotomycin synthesis by thymine and thymidine (Table 5) appears to be a specific effect on the efrotomycin pathway by thymine itself or its degradation products. Uridine reverses thymidine inhibition by preventing thymidine degradation to thymine. Thymine inhibition can be about $50 \%$ reversed by $\beta$-alanine, a degradation product of uracil, an effect which appears related to the flow of substrates to early efrotomycin biosynthetic steps and not to CoA synthesis because CoA synthesis may be fully inhibited under resting cell conditions by $40 \mu \mathrm{g} / \mathrm{ml}$ sodium salicylate, a known inhibitor of pantoate synthesis ${ }^{11}$, without any effect on efrotomycin synthesis.

Efrotomycin contains 9 methyl groups derived from methionine (Fig. 1) ${ }^{12}$, four $O$-linked, four $\mathrm{C}$-linked and one $\mathrm{N}$-linked groups. Several methylation inhibitors affect overall synthesis as shown in Table 4. Ethionine is profoundly inhibitory, without causing the synthesis of any new UV absorbing, efrotomycin related species; sinefungin leads to the accumulation of reduced amounts of a demethyl product, 20-O-demethylefrotomycin (A. KEMPF and K. WILson; personal communication).

In Streptomyces avermitilis, methylation inhibition is less profound and leads to the accumulation of a demethyl, or ethyl (when ethionine is used) analogues ${ }^{13)}$.

\section{Isotopic Labeling}

An example of the utility of the resting cell system is shown in Table 6. Propionate was

Table 5. Effect of purine and pyrimidine bases and nucleosides on efrotomycin synthesis in resting cells.

\begin{tabular}{ll}
\hline Nucleosides and bases & $\mathrm{IC}_{50}(\mathrm{mM})$ \\
\hline Cytidine & None \\
Uridine & None \\
Thymidine $^{\mathrm{a}}$ & 0.4 \\
Adenosine & 0.5 \\
Guanosine & None \\
Cytosine & None \\
Uracil & None \\
Thymine & 0.16 \\
Adenine & 0.7 \\
\hline
\end{tabular}

a Reversed by $1 \mathrm{~mm}$ uridine or cytidine.

b Partially reversed by $2.5 \mathrm{~mm} \beta$-alanine. Conditions are as in Table 4. 
used as precursor, in the most productive system, to prepare highly labeled efrotomycin for metabolic studies in animals. Lines $1 \sim 4$ represent preliminary trials in single flasks to illustrate the reproducibility of the system. Line 5 rep. resents the final large scale conditions to produce efrotomycin labeled to a specific activity approaching that of the precursor. Previous attempts to label in complex media showed much greater isotopic dilution. Label distribution had been confirmed prior to the final preparation by $\left[{ }^{13} \mathrm{C}\right]$ propionate incorporation at a single site (C-7), as was demonstrated for aurodox ${ }^{3)}$ (H. E. MERTEL et al.; personal communication).
Table 6. Extent of $\left[{ }^{14} \mathrm{C}\right]$ propionate incorporation into efrotomycin by resting cells.

\begin{tabular}{|c|c|c|c|}
\hline \multicolumn{2}{|c|}{$\left[1-{ }^{14}\right.$ C]Propionate, added } & \multirow{2}{*}{$\begin{array}{l}\text { Isolated } \\
\text { efrotomycin } \\
(\mu \mathrm{g} / \mathrm{mmol})\end{array}$} & \multirow[b]{2}{*}{$\mathrm{RMSA}^{\circ}$} \\
\hline$\mu \mathrm{Ci} / \mathrm{ml}$ & $\begin{array}{c}\text { Specific } \\
\text { activity } \\
(\mu \mathrm{g} / \mathrm{mmol})\end{array}$ & & \\
\hline 0.5 & 10 & 0.06 & 0.006 \\
\hline 200.0 & 14.5 & 3.7 & 0.26 \\
\hline 500.0 & 14.5 & 6.4 & 0.44 \\
\hline $1,000.0$ & 14.5 & 8.8 & 0.61 \\
\hline $1,000.0$ & 58.0 & 49.0 & 0.84 \\
\hline
\end{tabular}

a RMSA: Relative molar specific activity, efrotomycin/propionate.

Cells were harvested at 64 hours, and supplemented with $1.2 \%$ glucose. Incubation was for 72 hours except for the first line (16 hours). This experiment was performed before the routine addition of vitamin $B_{12}$.

\section{Discussion}

The resting cell system described here is highly productive, reaching $750 \mu \mathrm{g} / \mathrm{ml}$ of efrotomycin in 65 hours when supplemented with glucose and vitamin $B_{12}$. Our results indicate that efrotomycin synthesis, unlike a number of other secondary metabolites, is insensitive to glucose inhibition. Production of efrotomycin in complex or defined media, however, is repressed by glucose (unpublished results), suggesting that the glucose-sensitive step(s) lie outside the direct biosynthetic pathway to efrotomycin. Soy bean oil under conditions appropriate for lipase induction in the growth period is as effective a carbon source as glucose, after an initial lag period.

A system relatively independent of protein systhesis may be derived by the addition of chloramphenicol to cells harvested at $96 \sim 120$ hours without severe loss of biosynthetic capability of the cells to produce efrotomycin. Using such a system a variety of agents were screened for their effects on antibiotic synthesis. No amino acid has any significant effect on synthesis, apparently none being direct precursors of any portion of efrotomycin. Of the vitamins, only $\mathrm{B}_{12}$ has any effect, stimulating synthesis by about $15 \%$. Several metals and all membrane perturbants tested are inhibitors at low concentrations. Thymine or its breakdown products are inhibitors in a manner partially reversed by $\beta$-alanine, but unrelated to pantothenate biosynthesis. Cerulenin, as expected from its ability to inhibit polyketide biosynthesis, inhibits efrotomycin biosynthesis but thiolactomycin, an inhibitor of acyl carrier protein dependent fatty acid synthesis, is without activity, supporting the view that polyketide condensation is catalysed by a macrolide synthetase differing mechanistically from fatty acid synthetase. Several methylation inhibitors depress overall efrotomycin synthesis severely, rather than causing the accumulation of demethyl products, suggesting that early mandatory steps involving methylation may exist in the pathway.

The resting cell as described also has utility of studying terminal steps in efrotomycin synthesis, as exemplified here by glycosylation. Aurodox fed to a non-producing mutant is converted first to a monosaccharide and then to the disaccharide efrotomycin. Finally, the resting cell system is well suited for the preparation of highly radioactive labeled efrotomycin in a simple system with minimal precursor dilution.

\section{References}

1) Wax, R.; W. Maiese, R. Weston \& J. Birnbaum: Efrotomycin, a new antibiotic from Streptomyces lactamdurans. J. Antibiotics 29: 670 673, 1976

2) Berger, J.; H. H. Lehr, S. Teitel, H. Maehr \& E. Grunberg: A new antibiotic X-5108 of Strepto- 
myces origin. I. Production, isolation and properties. J. Antibiotics 26: 15 22, 1973

3) Liv, C.-M.; T. H. Williams \& R. G. Pitcher: ${ }^{13} \mathrm{C}-\mathrm{NMR}$ studies on the biosynthesis of aurodox (antibiotic X-5108). J. Antibiotics 32: 414 417, 1979

4) Dewey, R. S.; B. H. Arison, J. Hannah, D. H. Shih \& G. Albers-Schönberg: The structure of efrotomycin. J. Antibiotics 38: $1691 \sim 1698,1985$

5) Nielsen, J. B. K. \& L. Kaplan: A resting cell system for the synthesis of efrotomycin by Nocardia lactamdurans. Abstracts of the 85th Annual Meeting of the American Society for Microbiology, p. 240, Mar. 3 7, Las Vegas, 1985

6) Streicher, S. L. \& B. Tyler: Regulation of glutamine synthetase activity by adenylation in the grampositive bacterium Streptomyces cattleya. Proc. Natl. Acad. Sci. U.S.A. 78: 229 233, 1981

7) Khoo, J. C. \& D. Stemberg: Hormone sensitive triglyceride lipase from rat adipose tissue. Methods Enzymol. 72: 181 189, 1981

8) KAPLAN, L.; D. W. FINK \& H. C. FINK: Chelation and spectrophotometric determination of efrotomycin with aluminum ion. Anal. Chem. 56: 360 363, 1984

9) ŌMURA, S.: The antibiotic cerulenin, a novel tool for biochemistry as an inhibitor of fatty acid synthesis. Bacteriol. Rev. 40: 681 697, 1976

10) Yamada, M.; I. Nishida \& A. Kawaguchi: A new inhibitor of type II fatty acid synthetase. In Structure, Function to Metabolism of Plant Lipids. Eds., P.-A. SIEgenthaler \& W. EICHENBerger, pp. 37 40, Elsevier Science Publishers, Amsterdam, 1984

11) MAAS, W. K.: Pantothenate studies. II. Evidence from mutants for interference by salicylate with pantoate synthesis. J. Bacteriol. 63: 227 232, 1952

12) LIU, C.-M.; H. MAeHR, M. LeACh, M. LIU \& P. A. MilleR: Biosynthesis of aurodox (antibiotic X-5108). Incorporation of ${ }^{14} \mathrm{C}$-labelled precursors into aurodox. J. Antibiotics 30: 416 419, 1977

13) Schulman, M. D.; D. Valentino, O. D. Hensens, D. Zink, M. Nallin, L. Kaplan \& D. A. Ostlind: Demethylavermectins. Biosynthesis, isolation and characterization. J. Antibiotics 38: 1494 1498, 1985 